\title{
К ВОПРОСУ О ПРАВОВОЙ ПРИРОДЕ АДМИНИСТРАТИВНОГО ПРИОСТАНОВЛЕНИЯ ДЕЯТЕЛЬНОСТИ И ЕГО МЕСТЕ В СИСТЕМЕ МЕР АДМИНИСТРАТИВНОГО ПРИНУЖДЕНИЯ
}

\begin{abstract}
Аннотация: Предметом исследования является правовая природа административного приостановления деятельности и его место в системе мер административного принуждения. В статье проведен анализ правовой природы административного приостановления деятельности и определено его места в системе мер административного принуждения. При этом выявлены сущностные особенности административного принуждения, его специфика, субъекты и случаи применения данной административной меры. Автором определены субъективные и объективные предпосылки применения данной меры наказания, объективные предпосылки приостановления административной деятельности, а также обозначены основные подходы к применению данной меры наказания. В качестве методов исследования используется комплексный подход, объединяющий применение диалектико-материалистического подхода, метода системного анализа и нормативно-правового метода. Новизна исследования заключается в том, что автор выделяет ряд специфических особенностей, которые позволяют сделать вывод о том, что административное приостановление деятельности по своей природе не относится ни к одной из выделяемых наукой административного права групп мер административного принуждения. Административное приостановление деятельности, по сути, одновременно относится как к мерам административного предупреждения, так и к мерам административного пресечения. К особенностям данной правовой меры относится и то, что это единственное административное наказание, имеющее условный срок исполнения, а также тот факт, что к правоохраняемым объектам в данном случае относятся не только жизнь и здоровье людей, но и общественная или государственная безопасность.

Ключевые слова: административное приостановление деятельности, принуждение, наказание, мера, ответственность, предпосылка, последствие, административное предупреждение, административное пресечение, применение наказания.

Review: The subject of this study is the legal nature of administrative suspension of activity and its place in the system of administrative coercion. The article analyzes the legal nature of administrative suspension of activities and defines its place in the system of administrative coercion. At the same time it reveals the essential features of administrative coercion, its specificity, subjects and cases of the administrative measures. The author determines the subjective and objective conditions of application of this punishment, the objective conditions of suspension of administrative activities, and identifies the main approaches to the use of capital punishment.As the esearch methods the author uses the complex approach that combines the use of the dialectical materialist approach, the method of system analysis and the regulatory method.The novelty of the research lies in the fact that the author identifies a number of specific features that allow us to conclude that the administrative suspension of operations does not belong according to its nature to any group of administrative coercion identified within the science of administrative law. Administrative suspension of operations, in fact, at the same time applies to both measures of administrative warning and measures of administrative punishment. The special feature of this legal action is the fact that it is the only administrative punishment having a suspended sentence of execution, as well as the fact that the legally protected objects in this case are not only the human life and health, but also the public or state security.

Keywords: administrative warning, consequence, background, responsibility, measure, punishment, coercion, administrative suspension of activity, administrative constraint, application of punishment.
\end{abstract}

A дминистративно-правовое принуждение, по своей сути, в отличие от принуждения, представляет собой такую «...правоприменительную деятельность, осуществляемую государством и заключающуюся в применении уполномоченными государственными органами и лицами, предусмотренных законом мер и средств для поддержания правопорядка и обеспечение безопасности» $[9$, С. 23].

В связи с этим необходимо отметить, что использование мер административного принуждения выглядит объективной необходимостью в ряде случаев для реализации задач и функций исполнительной власти, а в некоторых ситуациях 
меры административного принуждения могут являться фактически единственным средством обеспечения нормальных условий функционирования государственной системы.

Исходя из анализа доктринальных подходов [2, $5,7]$ к сущности административного приостановления деятельности, можно выделить сущностные особенности данного наказания, как административного принуждения, которые заключаются в следующем:

- административное принуждение является внешним правовым воздействием, которое строго регламентировано действующими законодательными подходами;

- $\quad$ указанный вид принуждения должен осуществляться только уполномоченными на это специальными органами и лицами, действующими в соответствии со своей компетенцией;

- объектом административного принуждения следует рассматривать поведение личности;

- целью административного принуждения является соблюдение определенных административных норм, а также охрана существующих административно-правовых отношений в сфере государственного управления;

- административное принуждение в отличие от дисциплинарного принуждения не имеет связи с отношениями служебного подчинения;

- административное принуждение в отличие от уголовного или дисциплинарного принуждения возможно к применению как в отношении физических, так и юридических лиц;

- административное принуждение в отличие от уголовного не влечет юридического состояния судимости, а в отличие от дисциплинарного принуждения не рассматривается в обязательной связи с увольнением с места трудовой деятельности;

- административное принуждение, выступая одним из видов государственного принуждения, не может ущемлять честь и достоинство, а также причинять физические страдания личности. Согласно подходов теории административного права, исходя из целевого назначения, можно выделить три группы мер административного принуждения:

- меры административно-предупредительного характера;

- меры, направленные на административное пресечение;

- меры, предусматривающие административную ответственность.
Как правило, все указанные и определенные российским законодательством меры административного принуждения, вполне «вписываются» в одну из указанных групп.

Однако, такая специфичная мера принуждения как административное приостановление деятельности, имеет целый ряд специфичных особенностей, которые, не позволяют однозначно причислить эту меру к одной из указанных выше групп, и ставят проблему определения его правовой природы, с целью определения его места в системе мер административного принуждения.

C нормативной точки зрения административное приостановление деятельности выступает разновидностью административного наказания, установленного п. 9 ч. 1 ст. 3.2 КоАП РФ [1].

Как отмечает А.Б. Агапов, «административное приостановление деятельности относится к административным наказаниям, влекущим релятивные имущественные обременения» [3, С. 201].

Указанное административное наказание применимо к различным субъектам предпринимательской деятельности, в том числе к публичным организациям, а также к государственным некоммерческим учреждениям (например, к лечебным или образовательным) только при наличии предпосылок, которые установлены ч. 1 ст. 3.12 КоАП [1].

Данный вид наказания может быть применен только в качестве основного, т.е. он является самостоятельным, а в случае его избрания другие виды административных наказаний уже не назначаются.

Объективной стороной административного правонарушения выступает совокупность внешних признаков, к которым следует отнести: действие или бездействие, противоправные последствия, причинная связь между действием и последствиями, которые закреплены правовыми нормами КоАП, место и время, обстановка и обстоятельства правонарушения, а также способы и средства, с помощью которых совершено данное административное правонарушение.

Субъективная сторона рассматриваемого нами административного правонарушения включает в себя такие составляющие, как: вина, мотив и цель поведения правонарушителя.

Административное приостановление деятельности применимо в случаях:

- совершения наиболее опасных, по мнению законодателя, административных правонарушений, которые могут создать угрозу жизни или здоровью людей и иные угрозы; 
- в случае совершения административного правонарушения в определенной области деятельности;

- в ситуации совершения административного правонарушения, «посягающего на здоровье, санитарно-эпидемиологическое благополучие населения и общественную нравственность» (ч. 1 ст. 3.12 КоАП РФ).

Как отмечает В.Н. Комлев, «к правоохраняемым объектам относятся не только жизнь и здоровье людей, но и общественная безопасность или (применительно к пресечению деятельности по финансированию терроризма) государственная безопасность, что также образует существенную особенность данной меры административного принуждения» [6, С. 25].

Судья вправе вынести постановление о назначении рассматриваемого наказания только при наличии обстоятельств, которые свидетельствуют о значительной общественной опасности правонарушения, и когда не могут быть использованы менее обременительные наказания (см. абз. 2 ч. 1 ст. 3.12 КоАП), а при их отсутствии подлежит применению альтернативное и менее обременительное наказание, например административный штраф. Как отмечает И.А. Косицын, «обстоятельства, отягчающие ответственность, всегда квалифицируются по усмотрению судьи - последний, руководствуясь субъективными гуманитарными критериями, определяет наличие в деянии отягчающих признаков либо их отсутствие» [8, С. 19].

Следует согласиться с мнением И.В. Максимова, отмечающего, что определенную специфику рассматриваемой меры административного принуждения, составляет тот факт, что оно выступает по своей сути единственным административным наказанием с условным сроком исполнения - «в том случае, если будет установлено, что лицом устранены обстоятельства, послужившие основанием для его назначения, оно может быть снято» (судьей) [10, С. 173].

В сравнении с административными наказаниями, устанавливающими временные параметры ограничений правомочий нарушителя, предельный срок административного приостановления деятельности уступает по своей продолжительности лишению специального права и дисквалификации.

Важным выглядит, что административное приостановление деятельности выступает не только одной из наиболее распространенных публичных санкций, но и находит свое применение только в качестве основного административного наказания.

Санкции статей КоАП, устанавливающие административное приостановление деятельности, также как и другие административные наказания, которые исчисляются сутками (например, административный арест), не предусматривают определенного срока их применения и в этом случае соответствующее решение о временном сроке наказания всегда принимает судья.

Необходимо отметить, что КоАП установлен максимальный срок применения административного приостановления деятельности, но при этом не определен минимальный срок.

Это выглядит серьезным отличием от других административных наказаний, где ограничены временные пределы их применения как соответствующими минимальными, так и максимальными сроками (ч. 2 ст. 3.8, ч. 2 ст. 3.11 КоАП).

Согласно нормативных требований ч. 1 ст. 32.12 КоАП [1], «Постановление судьи об административном приостановлении деятельности исполняется судебным приставом-исполнителем немедленно после его вынесения». При этом судебный пристависполнитель самостоятельно может определить содержание мер принуждения, которые блокируют проведение хозяйственной деятельности субъекта предпринимательства. К таким мерам можно отнести, например, опломбирование (наложение специальных пломб) или опечатывание (наложение специальной печати) на помещения и места хранения материальных ценностей.

Виды хозяйственных объектов, в отношении которых осуществляются указанные властные действия, устанавливаются постановлением судьи о назначении административного приостановления деятельности.

Объектами, в отношении которых осуществляются подобные действия, могут быть как полностью производственное предприятие, так и его отдельное структурное подразделение или хозяйственное сооружение и производственное оборудование (поточная линия, конвейер, конкретный агрегат и др.). Виды объектов, подлежащие применению указанных специальных мер, устанавливаются судом в постановлении о применении наказания.

При этом как отмечает Р.А. Брунер, «судья исходит из презумпции недопущения необратимых последствий, которые могут произойти при установлении запретов и ограничений, например, не может быть блокирована деятельность производственных объектов, необходимых для функциони- 
рования и сохранности объектов жизнеобеспечения» $[4$, С. 16$]$.

Кроме судебного пристава, отдельные меры принимает сам суд (при нарушении законодательства о легализации доходов, полученных преступных путем, и финансировании терроризма, решает вопрос о мерах, необходимых для приостановления операций по счетам), либо иные органы, обладающие полномочиями в конкретных сферах регулирования.

По истечении срока действия административного приостановления деятельности должностное лицо проверяет устранение тех обстоятельств, которые послужили основанием для назначения данного административного наказания. В соответствии с ч. 5 ст. 32.12 КоАП РФ [1], если по результатам проверки будет установлено, что такие обстоятельства так и не устранены, то может быть составлен новый протокол об административном правонарушении и наложен новый временный запрет на осуществление деятельности до вынесения судьей постановления по делу.

В соответствии с положениями ч. 3 ст. 3.12, ч. 3, 4 ст. 32.12 КоАП РФ [1], лицо, устранившее допущенные ранее нарушения, может обратиться к судье с ходатайством о досрочном прекращении административного приостановления деятельности.

Также указанное ходатайство может быть подано и через институт Уполномоченного при Президенте Российской Федерации по защите прав предпринимателей.

В целом, проведенный анализ особенностей административного приостановления деятельности, свидетельствует о том, что это одна из наиболее специфичных мер административного принуждения установленных отечественным законодателем. Его особенности, позволяют выделять административное приостановление деятельности из числа других административных наказаний, по следующим признакам:

- признак целевого назначения. Особенность здесь видится в том факте, что указанная мера применяется в целях прекращения противоправного действия либо для устранения суще- ствующей угрозы, а не для предупреждения в порядке и понимании ч. 1. ст. 3.1. КоАП РФ;

- признак оснований применения. В качестве особенностей здесь можно выделить тот факт, что для назначения административного наказания недостаточно исключительно признаков административного правонарушения, предусмотренных КоАП РФ недостаточно.

Законодатель связывает его применение с наличие следующих условий имеющих дополнительный характер:

- в том случае, если «вид административного наказания не сможет обеспечить достижение цели административного наказания» (ч. 2 ст. 3.12 КоАП РФ [1]);

- в том случае, когда налицо существование «угрозы жизни или здоровью людей, возникновения эпидемии, эпизоотии, заражения (засорения) подкарантинных объектов карантинными объектами, наступления радиационной аварии или техногенной катастрофы, причинения существенного вреда состоянию или качеству окружающей среды» (ч. 1 ст. 3.12 КоАП РФ) [[1]].

Завершая настоящую статью, отметим, что выявленные нами особенности исследуемого вида административного принуждения, позволяют сделать вывод о том, что эта мера, по сути, одновременно относится и к мерам административного предупреждения, и к мерам административного пресечения.

К другим особенностям данного вида административного наказания относится то, что оно имеет условный срок исполнения, а также тот факт, что к правоохраняемым объектам здесь относятся не только жизнь и здоровье людей, но также и общественная или государственная безопасность.

Указанные особенности, позволяют считать, что административное приостановление деятельности, по своей природе, не относится ни к одной из выделяемых наукой административного права групп мер административного принуждения и стоит «особняком» в системе мер административного принуждения в целом.

\section{Библиография:}

1. Кодекс Российской Федерации об административных правонарушениях. Федеральный закон от 30.12 .2001 № 195-ФЗ (ред. от 11.01.2015) [Текст] // Собрание законодательства РФ. - 07.01.2002. - № 1 (ч. 1 ). - Ст. 1.

2. Агапов, А. Б. Административная ответственность [Текст] / А. Б. Агапов. - М. : Юрайт, 2012. - 435 с.

3. Агапов, А. Б. Постатейный комментарий к кодексу РФ «Об административных правонарушениях», расширенный, с использованием материалов судебной практики [Текст] / А. Б. Агапов. - 4-е издание, испр. и доп. - М. : Статус, 2011. - 437 c. 
Административное и муниципальное право 3 (87) • 2015

4. Брунер, Р. А. Административное приостановление деятельности [Текст] / Р. А. Брунер : автореф. дисс.... канд. юрид. наук. - М., 2009. - 31 с.

5. Кожевников, С. Н. О принуждении в правоохранительной деятельности советского государства [Текст] / С. Н. Кожевников // Сб. уч. трудов Свердловского юридического ин-та. Проблемы применения советского права. Свердловск, 1973. - Вып. 22. - С. 122-126.

6. Комлев, В. Н. Административное приостановление деятельности [Текст] / В. Н. Комлев // Административное право и процесс. - 2007. - № 2. - С. 25-32.

7. Коренев, А. П. Нормы административного права и их применение [Текст] / А. П. Коренев. - М. : Наука, 1978. - 276 с.

8. Косицин, И. А. Административное приостановлении деятельности в системе мер административного принуждения [Текст] / И. А. Косицын // Омский научный вестник. - 2004. - №5. - С. 18-26.

9. Лановая, Г. М. Государственно-правовое принуждение в оперативно-исполнительной форме применения права [Текст] / Г. М. Лановая // Юридические науки. - 2006. - №1(17). - С. 91-101.

10. Максимов, И. В. Генезис правовых основ регламентации административного приостановления деятельности в России [Текст] / И. В. Максимов // Правовая политика и правовая жизнь. - 2011. - №1. - С. 168-173.

11. Резникова, А. А. Административное приостановление деятельности как мера административного принуждения [Текст] / А. А. Резникова : автореф. дисс. канд. юр. наук. - М., 2009. - 30 с.

\section{References (transliterated):}

1. Kodeks Rossiiskoi Federatsii ob administrativnykh pravonarusheniyakh. Federal'nyi zakon ot 30.12.2001 № 195-FZ (red. ot 11.01.2015) [Tekst] // Sobranie zakonodatel'stva RF. - 07.01.2002. - № 1 (ch. 1). - St. 1.

2. Agapov, A. B. Administrativnaya otvetstvennost' [Tekst] / A. B. Agapov. - M. : Yurait, 2012. - 435 s.

3. Agapov, A. B. Postateinyi kommentarii k kodeksu RF «Ob administrativnykh pravonarusheniyakh», rasshirennyi, $\mathrm{s}$ ispol'zovaniem materialov sudebnoi praktiki [Tekst] / A. B. Agapov. - 4-e izdanie, ispr. i dop. - M. : Status, 2011 . - 437 s.

4. Bruner, R. A. Administrativnoe priostanovlenie deyatel'nosti [Tekst] / R. A. Bruner : avtoref. diss.... kand. yurid. nauk. - M., 2009. - $31 \mathrm{~s}$.

5. Kozhevnikov, S. N. O prinuzhdenii v pravookhranitel'noi deyatel'nosti sovetskogo gosudarstva [Tekst] / S. N. Kozhevnikov // Sb. uch. trudov Sverdlovskogo yuridicheskogo in-ta. Problemy primeneniya sovetskogo prava. - Sverdlovsk, 1973. Vyp. 22. - S. 122-126.

6. Komlev, V. N. Administrativnoe priostanovlenie deyatel'nosti [Tekst] / V. N. Komlev // Administrativnoe pravo i protsess. 2007. - № 2. - S. 25-32.

7. Korenev, A. P. Normy administrativnogo prava i ikh primenenie [Tekst] / A. P. Korenev. - M. : Nauka, 1978. - 276 s.

8. Kositsin, I. A. Administrativnoe priostanovlenii deyatel'nosti v sisteme mer administrativnogo prinuzhdeniya [Tekst] / I. A. Kositsyn // Omskii nauchnyi vestnik. - 2004. - №5. - S. 18-26.

9. Lanovaya, G. M. Gosudarstvenno-pravovoe prinuzhdenie v operativno-ispolnitel'noi forme primeneniya prava [Tekst] / G. M. Lanovaya // Yuridicheskie nauki. - 2006. - №1(17). - S. 91-101.

10. Maksimov, I. V. Genezis pravovykh osnov reglamentatsii administrativnogo priostanovleniya deyatel'nosti v Rossii [Tekst] / I. V. Maksimov // Pravovaya politika i pravovaya zhizn'. - 2011. - №1. - S. 168-173.

11. Reznikova, A. A. Administrativnoe priostanovlenie deyatel'nosti kak mera administrativnogo prinuzhdeniya [Tekst] / A. A. Reznikova : avtoref. diss. kand. yur. nauk. - M., 2009. - 30 s. 